\title{
A Comparative Evaluation of Two Computer Supported Collaborative Work Systems for Supporting Collaborative Business Process Modeling Activities
}

Duygu FINDIK COŞKUNÇAY, Ass. Prof. Dr. Atatürk University, Faculty of Economics and Administrative Sciences, Erzurum, Turkey. Middle East Technical University, Informatics Institute, Ankara, Turkey, duygu.findik@atauni.edu.tr,ORCID: 0000-0002-8932-5615

Murat Perit ÇAKIR, Ass. Prof. Dr. Middle East Technical University, Informatics Institute, Ankara, Turkey, perit@metu.edu.tr, ORCID: 0000-0003-4295-1245

ABSTRACT In this study, a comparative evaluation of different Computer-Supported Collaborative Work (CSCW) environments was conducted to reveal their constraints and affordances for supporting synchronous collaborative business process modeling (cBPM) activities online. For this purpose, two case studies were carried out with two CSCW systems that differ in terms of their interaction design features for supporting joint work. The dual-eye tracking method was employed to monitor how the participants focused their attention on the shared workspace during cBPM tasks. An interaction analysis was performed on the communicational content exchanged by the participants in chat messages and activities performed on the shared working area in light of the coordination, communication, awareness, group decision-making and team-building aspects of collaboration. The interaction analysis suggested that the design of the systems significantly affected the participants' performance and the interaction quality throughout cBPM. In addition, a content analysis was conducted to determine the effects of different interaction design methodologies on the formation of the Business Process Modeling (BP Modeling) phases namely elicitation, formalization, validation and verification. The interaction design features of the systems were found to significantly affect the organization of the BP Modeling phases. Based on the findings, some design suggestions were made to enhance the efficiency of collaboration in cBPM practices. It is expected that the results of the study will serve as a guideline for system designers in designing an effective synchronous $c B P M$ tool, and for end users in choosing a system for their synchronous CBPM practices.

Keywords : business process modeling, collaborative business process modeling, computer supported modeling, group interaction 


\title{
İşbirlikli İş Süreç Modelleme Faaliyetlerini Destekleyen İki Bilgisayar Destekli İşbirlikli Çalışma Sisteminin Karşılaştırmalı Bir Değerlendirilmesi
}

ÖZ

\begin{abstract}
Bu çalışmada, bilgisayar destekli işbirlikli iş süreçleri modelleme (cBPM) etkinliklerinin çevrimiçi olarak desteklenmesi sürecinde kısıtlamalar ve kolaylıkları ortaya koymak amactyla farklı Bilgisayar Destekli İşbirliği Çalışma (CSCW) ortamlarının karşılaş̧ırmalı bir değerlendirmesi yapılmıştır. Bu amaçla, etkileşim tasarım özellikleri açısından farklılık gösteren iki CSCW sistemi ile ortak çalışmayı destekleyen iki durum çalışması yürütülmüştür. Katılımcıların dikkatlerini cBPM görevleri sırasında paylaşılan çalışma alanına nasıl odakladıklarını gözlemlemek için ikili göz izleme yöntemi kullanılmıştır. Katılımcılar tarafından sohbet mesajları ile gönderilen iletişimsel içerik ve paylaşılan çalışma alanındaki aktiviteler üzerinde koordinasyon, iletişim, farkındalık, grup olarak karar verebilme ve takım oluşturma boyutları ışı̆̆ında bir etkileşim analizi gerçekleştirilmiştir. Etkileşim analizi, sistem tasarımlarının katılımcıların performansını ve etkileşim kalitesini cBPM boyunca önemli ölçüde etkilediğini göstermiştir. Ayrıca, farklı etkileşim tasarım metodolojilerinin İş Süreçleri Modelleme (BP Modelleme) aşamaları olan ortaya çıkarma, biçimlendirme, geçerleme ve doğrulama üzerine etkilerini belirlemek için bir içerik analizi gerçekleştirilmiş̧ir. Sistemlerin etkileşim tasarım özelliklerinin, BP Modelleme aşamalarının organizasyonunu önemli ölçüde etkilediği bulunmuştur. Bulgulara dayanarak, cBPM uygulamalarında işbirliği etkinliğini artırmak için bazı tasarım önerileri yapılmıştır. Çalışma sonuçlarının, sistem tasarımcılarının etkin bir eş zamanlı cBPM aracı tasarlamaları ve son kullanıcıların eş zamanlı cBPM uygulamalar için sistem seçimlerinde bir kılavuz görevi görmesi beklenmektedir.
\end{abstract}

Anahtar Kelimeler: iş süreci modelleme, işbirlikli iş süreci modelleme, bilgisayar destekli modelleme, grup etkileşimi

\section{Introduction}

In recent years, organizations have started to describe their core procedures in terms of business processes and invested considerable effort in defining these processes within operational models (Roser \& Bauer, 2005). Business Process Modeling (BP Modeling) is a collaborative activity that involves a number of stakeholders who possess the fundamental knowledge of the processes or goals of an organization (Rittgen, 2010). Modeling and managing collaborative business processes involves new challenges, mainly regarding the ability to cope with change, decentralization, and the required support for interoperability (Roser \& Bauer, 2005). In overcoming these challenges, BP Modeling activities can potentially benefit from Computer-Supported Collaborative Work (CSCW) practices. CSCW systems are primarily based on computer-mediated communication tools, but they provide additional awareness and coordination features tailored to the needs of group members who work together to accomplish a particular goal at a specific work setting (Bannon \& Schmidt, 1989; Dourish \& Bellotti, 1992). Process modeling is usually performed either in an asynchronous or 
synchronous manner with the help of computer-mediated communication tools (Riemer et al., 2011). Asynchronous modeling is the most commonly used modeling approach in the BP Modeling domain, where the process is initiated by one user while other users contribute to the evolving model at a different time and most probably at a different location. Email, collaborative writing and content management systems are often used for asynchronous collaboration among stakeholders. In contrast, the synchronous modeling approach allows stakeholders to engage in modeling at the same time without having to be at the same location. In this case, communication is usually mediated by teleconferencing, video chat applications, instant messengers, chat and shared drawing tools, which are based on the exchange of texts and diagrams among multiple users (Zemel, 2005).

According to Riemer et al. (2011), commercial BP Modeling tools predominantly support the asynchronous modeling approach. However, certain tools in the market such as ARISalign (Software AG, 2012) and CoMoMod (Dollmann et al., 2011) use the synchronous process modeling approach, which supports concurrent modeling activities during collaborative process modeling. In addition, the Collaborative Cheetah Experimental Platform (cCEP) developed for academic research provides an environment that supports the synchronous approach (Forster et al., 2013). Despite using the same modeling approach, each environment offers different features to facilitate synchronous collaborative work. For example, in some systems including ARISalign, only one user has the right to edit the model at a time; however, in others such as CCEP, all the stakeholders can use the whiteboard area concurrently and see all the changes instantly without having to wait for the other users (Forster et al., 2013).

In this study, the constraints and affordances provided by systems with different CSCW interaction methodologies for supporting CBPM processes were explored through two case studies. To analyze the interaction between the participants during the cBPM practices, publicly available tools ARISalign and VMTChat (Stahl, 2009) were used as a synchronous CSCW environment. In the VMTChat platform, the stakeholders can use the modeling area concurrently. An activity performed by a group member can be simultaneously seen by other members. However, in ARISalign, only the active user, who first accesses the model, has the right to edit the model and other users have to wait for the active user to complete his editing on the whiteboard. The activities performed by the active user are temporarily disabled for other group members when performing the modeling. In addition to the difference in this interaction design of the shared whiteboard, the communication designs of the two systems also differ. The VMTChat environment has a chat window placed on the right side of the shared modeling area. Any message sent by a group member is open to all members. However, in ARISalign, the participants can communicate using the discussion board, in which they can initiate new topics and organize their communication. In this system, the discussion board and shared modeling area are on two different pages. Therefore, messages cannot be seen while the modeling activities are being performed.

In this study, an interaction analysis was performed on the communicational contents and modeling activities of the two interaction methodologies in light of the following aspects of the coordination theory; coordination, communication, awareness, group decision-making 
and team-building (Malone \& Crowston, 1994). The examination of the interaction between the participants based on these aspects demonstrated how different interaction methodologies can affect the efficacy of interaction among participants and how a system should be designed and improved to increase the efficiency of cBPM practices. In addition, the current study aimed to make the CBPM phases of elicitation, formalization, validation and verification more visible to understand the formation of these phases in different CSCW interaction designs. It was observed that differences in the interaction design of the system significantly affect the formation of the BP Modeling phases. At the end of this study, system design recommendations are made to enhance collaboration in collaborative modeling. The results of the research can serve as a guideline for system designers in designing a synchronous collaborative BP Modeling tool, and for customers in choosing a tool for their synchronous modeling practices. In this study, the following research questions were pursued:

"How different interaction methodologies of CSCW systems affect coordination, communication, awareness, group decision-making and team building aspects of collaborative group interactions throughout cBMP?"

"How different interaction methodologies of CSCW systems affect the organization of elicitation, formalization, validation and verification phases of $\mathrm{BP}$ modeling throughout cBPM?"

This paper is structured as follows: Section 2 presents the theoretical background and provides an overview of BP Modeling and CBPM. In Sections 3 and 4, the research design, data collection and data analysis are given, followed by Sections 5 and 6 that present the results, discussion of the main findings and limitations, respectively.

\section{Theoretical Background}

Business process management life cycle consists of design and analysis, configuration, enactment and evaluation phases (Weske, 2007). This life cycle starts with the design and analysis phase. The business process design phase has a central role in the identification, reviewing and representation of business processes (Weske, 2007) and ensures that these processes are effective and optimized, meet customer requirements, and support and sustain organizational development and growth (Cousins \& Stewart, 2002). The design phase seeks answers to the following questions; "Who does what, in what sequence, what services or products are produced and what software systems and data are used to support the process?" (Davis \& Brabander, 2007).

Mauser et al. (2009) suggested that the early phases of a business process design is critical for ensuring the validity of the outcome of the business processes. BP Modeling and identification is performed to demonstrate the processes of an enterprise so that the current process can be analyzed and improved. The early design of the BP Modeling processes consists of three important phases: elicitation, formalization, validation and verification (Frederiks \& Van der Weide, 2006). Process of modeling is described as "a goal-driven dialogue between a number 
of participants who communicate with each other and build their discussion on what has been discussed before. The participating roles are either domain experts who generate and validate statements about the domain, or system analysts who create and verify formal models" (Hoppenbrouwers et al., 2005). This shows that BP Modeling is a multi-stakeholder activity in which the team members jointly discuss, design and document all business processes (Riemer et al., 2011).

Communication, coordination, awareness, group decision-making and team-building each play an important role in process modeling (Riemer et al., 2011). Providing software support for these activities, CSCW tools are essential in terms of facilitating group interactions at a distance (Malone \& Crowston, 1994; Salas et al., 2008). Team members need to communicate with each other to explain their changes, coord inate the modeling activities and agree on terms and definitions. Throughout the process, stakeholders should be able to monitor the changes made by other team members and access information about the time, author and type of change that has been made. Different team members assume different roles; someone is in charge of the modeling whereas others deliver information or review the model. Each team member contributes to the joint modeling activities according to their respective roles. Using the CSCW tools, these CBPM activities can be easily and effectively performed (Riemer et al., 2011).

In recent years, cBPM has attracted the attention of several researchers, who investigated cBPM from different perspectives. For instance, Baghaei et al. (2007) evaluated the effectiveness of the COLLECT-UML tool and showed that the use of collaborative systems improved students' domain knowledge. Basheri (2010) examined computer-supported collaborative learning environments such as COLER, COLLECT-UML, CoLeMo and AUTOCOLLEAGUE using the Unified Modeling Language (UML). The study examined the type and frequency of contributions of students in the chat system and evaluated these systems in terms of their support for interactive learning. Similarly, Riemer et al. (2011) investigated the collaborative nature of several existing BP Modeling tools; CA ERwin Process Modeler, ARIS Design Platform 7, Enterprise Architect 8, iGrafx Process Modeler 2011, Microsoft Visio 2010, Business Modeler Advanced 7, Signavio Process Editor, BONAPART Collaborative, Adonis, Savvion Process Manager and Innovator for Business Analysts. These development tools were evaluated using three types of criteria; process modeling, collaboration and technical. Based on the results, the researchers concluded that tool designers perceive modeling as predominantly asynchronous and none of the products allows synchronous modeling on the same object. Hogrebe et al. (2011) performed an eye tracking experiment for the measurement and assessment of user satisfaction with modeling languages such as the extended Eventdriven Process Chain (eEPC) and the oriented Event-driven Process Chain (oEPC). The authors stated that the most important requirements for the modeling language in BP Modeling are; being 'complete', 'easy-to-understand' and 'easy-to-use'. Mendling et al. (2012) proposed a collaborative process modeling framework evaluating the following three BP Modeling tools; Collaborative Modeling Architecture (COMA), Signavio Process Editor and Software AG ARISalign \& ARIS Community in terms of their collaboration aspects, namely awareness, communication, coordination, group decision making and team and community 
building. Forster et al. (2013) conducted a study, in which they developed hypotheses to examine process of synchronous process modeling. The researchers planned to develop visualizations, algorithms and metrics to make qualified assertions on cBPM. In addition to these studies concentrated on collaboration, Petrusel and Mendling (2013) performed a single user BP Modeling activity with eye tracking technology to investigate the formalization phase of process modeling to explore the relationship between the relevant region of a process model and the answers given to the comprehension questions. Pinggera et al. (2013) used the eyetracking technology to examine the formalization phase of BP Modeling from a single user perspective. The researchers suggested that the modelers have a good understanding of the current task if participants have a shorter average fixation duration on the case when reading.

To the best of our knowledge, there is limited research on the interaction design of systems to evaluate their effects on the performance of participants when performing cBPM activities and on the formation of BP Modeling phases. This study aimed to fill this gap in the literature by providing an investigation into these areas through a qualitative case study focusing on how a group of users organized their CBPM activities within two CSCW systems that offer various features to support collaborative modeling processes online.

\section{Research Design}

In this study, a qualitative exploratory research methodology was employed to closely analyze the interactions among the participants while they were engaged with cBPM work in two different CSCW settings. This research methodology typically focus on small samples and case studies to understand the behavioral and interpersonal relationships of participants in their natural environment (Cherry \& Robillard, 2008).

The following tasks were carried out for the design of this case study. Initially, two valid cases were selected from the ongoing business processes of the Informatics Institute of the Middle East Technical University (METU), Turkey. In selecting the processes, it was considered that the processes would have similar complexity to prevent any biases that could be due to nonequivalent business processes. Complexity measures tell us whether a model is easy or difficult to understand (Gruhn \& Laue, 2006). Process I, "New Course Proposal Evaluation Process", was modeled in the VMTChat environment and Process II, "Debit Entry Process", was modeled in ARISalign.

In this study, purposive sampling procedure was applied to obtain information from a smaller number of carefully selected cases and generate representative and contrasting cases (Teddlie $\& Y u, 2007)$. A team was formed with three software engineers, who were also graduate students at the Informatics Institute and have professional experience with BP Modeling concepts and tools, to represent a geographically dispersed team scenario. The team members were all Turkish natives; therefore, to prevent any language problems or biases, Turkish was chosen as the interaction language. Similarly, the processes and process elements as well as communication during cBPM activities were all in Turkish. After the formation of the team, each member was assigned a role. One member was designated as the Information Provider 
(IP). Only the IP was provided with detailed information about the business processes. The IP was responsible for informing the modelers about these processes. The remaining two members, who had 2-5 years of work experience in professional software development, were assigned the modeler role as M1 and M2, which made them responsible for modeling the business processes according to the information given by the IP. Table 1 presents the demographic profile of the team members. The modelers reportedly had abilities and experience related to BP Modeling. In addition, the IP had prior experience in BP Modeling and was capable of model reading. Therefore, the team was considered suitable to represent BP Modeling scenarios.

Table 1 - Demographic profile of the team members

\begin{tabular}{|c|c|c|c|}
\hline Demographic Characteristics & $I P$ & M1 & M2 \\
\hline Gender & Male & Female & Female \\
\hline Age & 29 & 30 & 25 \\
\hline Occupation & Research Assistant & $\begin{array}{l}\text { Research } \\
\text { Assistant }\end{array}$ & $\begin{array}{l}\text { Research } \\
\text { Assistant }\end{array}$ \\
\hline Familiarity with peers & Yes & Yes & Yes \\
\hline Ability on group works & Good & Good & Good \\
\hline $\begin{array}{l}\text { Member's thought about } \\
\text { team strength }\end{array}$ & $\begin{array}{l}\text { Not very strong but } \\
\text { strong enough }\end{array}$ & Strong & Strong \\
\hline $\begin{array}{l}\text { Previous experiences on } \\
\text { CSCW environments }\end{array}$ & Google Drive (Docs) & - & - \\
\hline $\begin{array}{l}\text { Previous experiences on BP } \\
\text { Modeling with CSCW } \\
\text { environment }\end{array}$ & - & - & - \\
\hline $\begin{array}{l}\text { Member's evaluation on own } \\
\text { process modeling ability }\end{array}$ & - & Neutral & Pretty Good \\
\hline $\begin{array}{l}\text { Previously used } \quad \text { BP } \\
\text { Modeling notations }\end{array}$ & - & $\begin{array}{l}\text { UML activity } \\
\text { Diagram, Data } \\
\text { Flow Diagram, } \\
\text { eEPC }\end{array}$ & $\begin{array}{l}\text { UML activity } \\
\text { Diagram, Data } \\
\text { Flow Diagram, } \\
\text { eEPC }\end{array}$ \\
\hline $\begin{array}{lcc}\text { Previously used } & \text { BP } \\
\text { Modeling environments } & \end{array}$ & - & $\begin{array}{l}\text { Microsoft Office } \\
\text { Visio and } \\
\text { Enterprise } \\
\text { Architect }\end{array}$ & $\begin{array}{l}\text { Microsoft } \\
\text { Office Visio and } \\
\text { ARIS Business } \\
\text { Architect }\end{array}$ \\
\hline
\end{tabular}

Several computer-mediated communication options to facilitate BP modeling practices were examined such as COMA, CoMoMod, cCEP. However, commercial BP modeling tools predominantly support asynchronous modeling (Riemer et al., 2011) and most of the modeling tools were not publicly available. Therefore, VMT Chat (Stahl, 2009) and ARISalign (Software AG, 2012) CSCW systems were selected as synchronous communication channels. In the VMTChat environment, all the team members can use the shared whiteboard at the same time. 
They can individually work on the same object or a different part of the model. The system has a 'Current Users' window that shows the online team members. There is a chat window on the right side of the system panel where the team members' messages are shown in different colors. The system keeps all the conversations, which can be loaded onto the chat window upon request. In addition, the system displays a notification at the bottom of the message window about the user writing the message. The system utilizes a referencing tool that enables the team members to refer to any object on the whiteboard and directly make comments about this object. Using this reference tool, the team member can also refer back to any previous message in the chat window. Furthermore, the history bar in the system shows the previous versions of the models. Figure 1 presents a screenshot of the VMTChat environment.

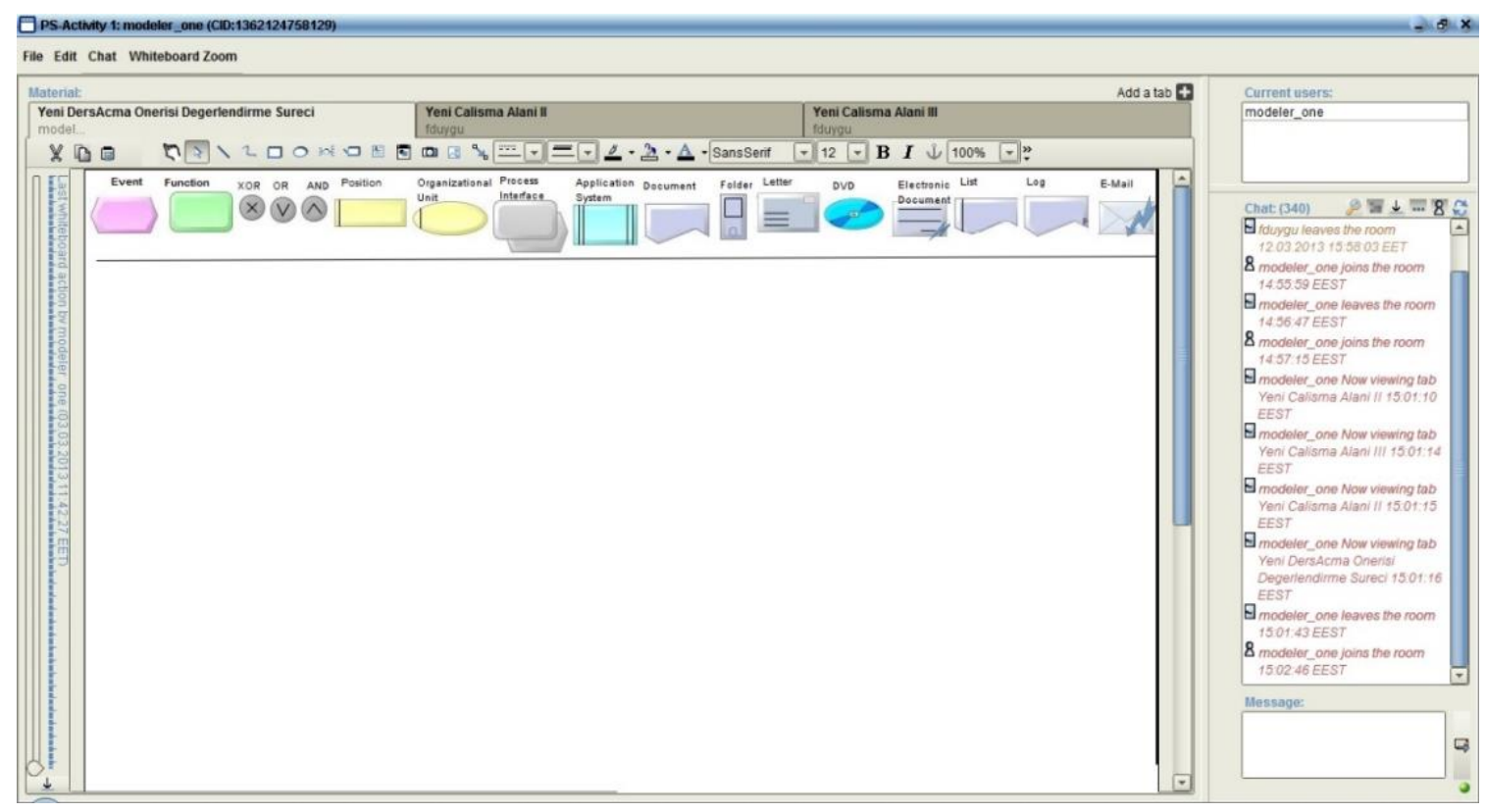

Figure 1 - VMTChat Environment

Before the case study was conducted, the team members were given a basic training in modeling elements and systems, in which the VMTChat environment was also introduced. Although the modelers already knew about the modeling rule, brief information about model elements was given as a reminder. In this training, the team members had the opportunity to see how each user interface element worked; including the chat window, messaging window and the referencing tool on the whiteboard. Before the case study, some short modeling exercises were performed with the modelers to ensure that they became acquainted with the VMT system.

ARISalign has a shared whiteboard area; however, the team members cannot use this area at the same time. Only the active user, who first accesses the model, has the right to edit the model, and other users have to wait for this user to complete his/her editing on the whiteboard. The ARISalign system has a discussion board on a different page. As in the VMT system, the team members were introduced the ARISalign cBPM environment before the case study. They were informed about the communicational features of the system as well as other features for 
using model elements and managing the shared whiteboard. Figures 2 and 3 show the whiteboard and the discussion panel of ARISalign, respectively.

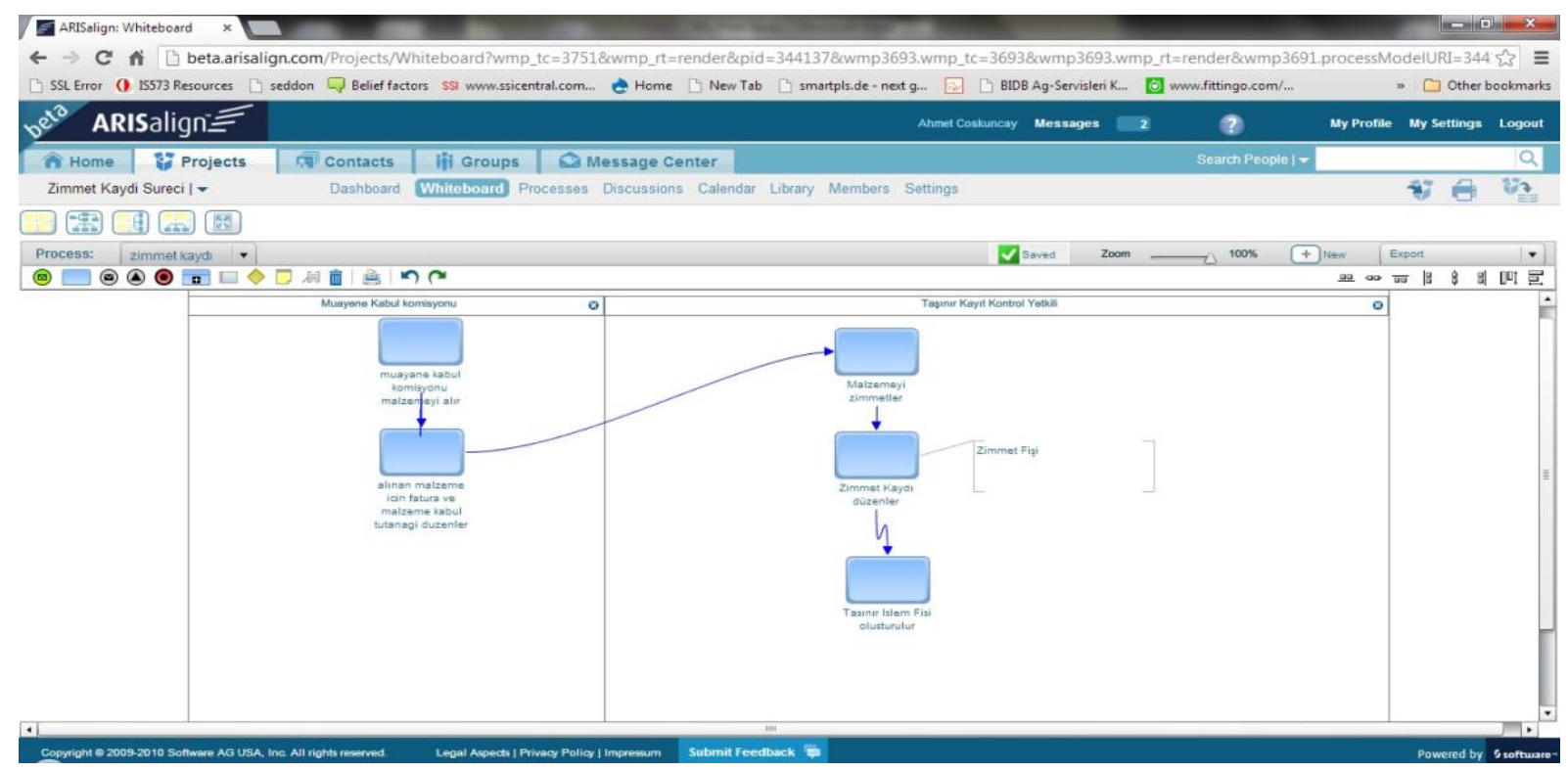

Figure 2 - ARISalign Whiteboard Area

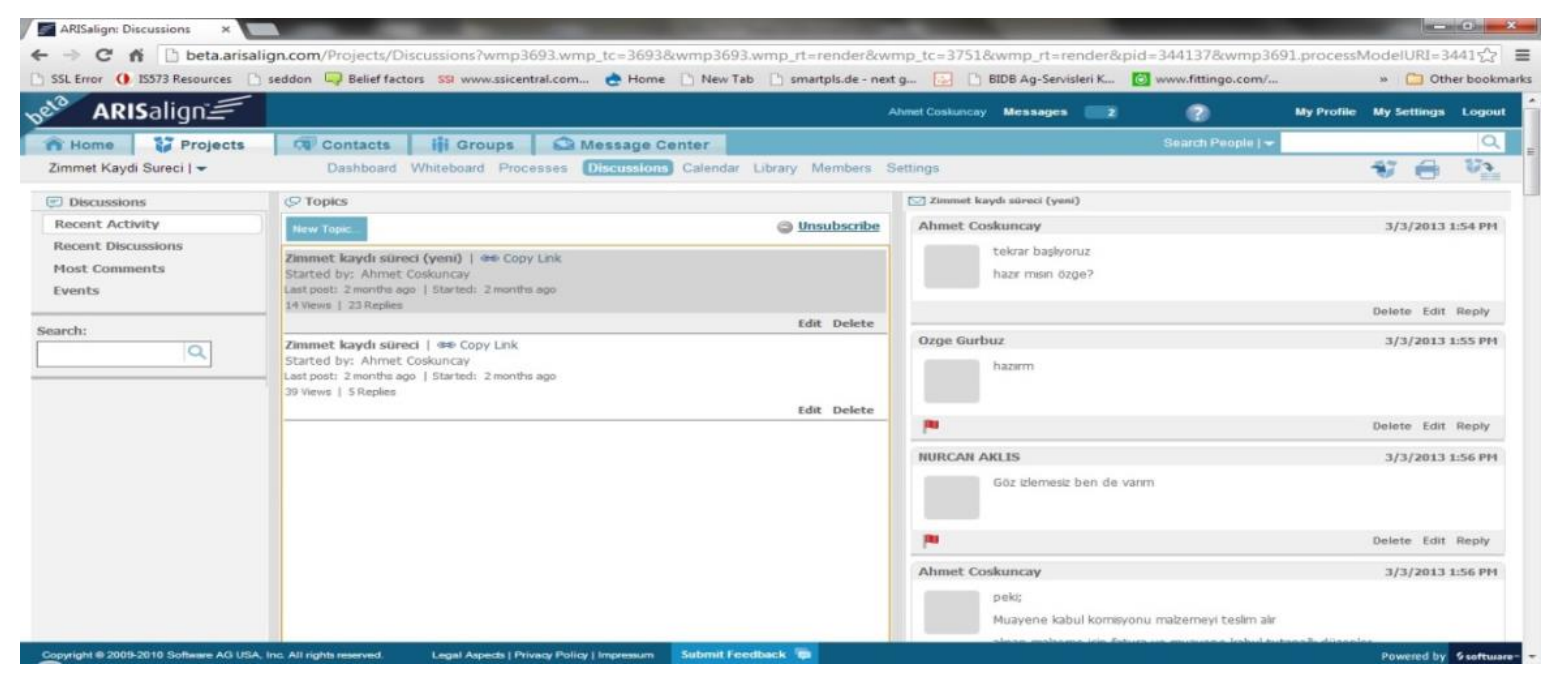

Figure 3 - ARISalign Discussion Panel

In this study, two different modeling languages, i.e. eEPC and BPMN, were used in the two different modeling tools, i.e. VMTChat and ARISAlign respectively. This introduces a potential threat to the validity of the study. However, as both of these languages support describing similar perspectives of a business process, and our analysis focuses on how both systems support collaborative team work in the context of business process modeling, the effect of this issue on the validity of our study is expected to be minor. Moreover, studying the impact of using different modeling languages in collaborative business process modeling is not within the scope of our study and it would require further research. 
The case studies were conducted in two sessions. In the first session, Process I was discussed and modeled in the VMTChat environment, which lasted 50 minutes. Following a 45-minute break, the second session was conducted for Process II in ARISalign. This session was completed in 31 minutes.

\section{Data Collection \& Data Analysis}

The participants performed synchronous collaborative process modeling activities in VMTChat and ARISalign environments. Eye tracking technology, and specifically the dual eye tracking technique, was used to monitor the eye movements of the modelers to see where they were looking at any given time and the sequence in which their gaze shifted from one location to another. For this purpose, two Tobii TX2-60 eye trackers were used to sample the gaze information of the two modelers during the session, which provided a screen recording of the shared environment overlaid with eye fixation information. To analyze how the users allocated their attention to the shared workspace, the time-synchronized screen records of collaborative model building sessions were examined in detail using the Transana software (Woods \& Fassnacht, 2007). This program allows researchers to analyze two or more videos synchronously by playing them side by side. The dual eye-tracking records of collaborative model building sessions, VMTChat's system log and messages in the ARISalign constituted the data sources of the study. It was not possible to access the logs of ARISalign; therefore, the written communication of the team members on the discussion board was exported to Microsoft Excel 2010 environment including the timestamps. To understand how the interaction methodologies affected the collaboration between the team members, an interaction analysis was performed on the communicational content obtained from the chat messages and modifications on the whiteboard. The interaction analysis was performed in light of the following aspects of collaboration: coordination, communication, awareness, group decision-making and team-building (Malone \& Crowston, 1994; Mendling et al., 2012).

In addition, to understand how the interaction methodologies of the systems affected the formation of the BP Modeling phases, a content analysis was performed on the communicational content and modifications on the whiteboard. To this end, interactions through the messages and the activities on the shared whiteboards were examined with respect to the timeline. Each interaction in the timeline was coded according to the BP Modeling phases implemented at that timestamp. The timestamps of interactions were then classified as elicitation, formalization, validation or verification based on the content of the messages. Elicitation referred to the messages related to information transfer about the business process; formalization indicated any activity or comments about modeling; validation was used when the IP identified, corrected or managed an element; and finally verification was chosen when the modelers commented on or made corrections related to an issue they introduced. Messages that were not related to these phases were extracted from the analysis. 


\section{Results}

\section{VMT Chat: Interaction analysis based on the aspects of collaboration}

Coordination: The coordination of team members was observed throughout the synchronous process modeling in VMTChat. The following examples illustrate how the system supported coordination during this process.

No instruction was given to the team members about the coordination of the BP Modeling phases before the activity to ensure that BP Modeling was performed spontaneously. At the beginning of the modeling session, team members discussed the preferred modeling approach to reach a consensus on how they would coordinate the group to accomplish the modeling activity. The related interaction is presented in Table 2. After the team members greeted each other, the IP informed the modelers about the name of the process and gave brief information about the process (see Lines 8, 14 and 15). However, the information transfer was interrupted by M2's message in Line 16 that queried the modeling approach they would take. M2 wanted to ask for M1's opinion about the coordination of the modeling activity; whether they would perform the modeling after the IP gave all the information about the process or during the information transfer. M1 stated that she preferred the second modeling approach, which was confirmed by M2 (in Line 18) and the IP (in Line 19). The team members proceeded with the agreed modeling approach, in which elicitation and formalization stages did not occur in a linear order. It is seen that the team members preferred to conduct these phases concurrently; rather than first taking the whole information about the process (elucidation) and then performing modeling (formalization).

Table 2 - A snippet of chat communication for coordination

\begin{tabular}{|c|c|c|c|}
\hline Line & Timestamp & Team Member & Statement \\
\hline 1 & 03:41:32 & IP & Hi guys / Merhaba arkadaşlar \\
\hline 2 & 03:41:37 & IP & I am Ahmet / Ben Ahmet \\
\hline 3 & & M1 & Hi / Merhaba \\
\hline 4 & 03:41:39 & M1 & I am Nurcan / Ben Nurcan \\
\hline 5 & 03:41:43 & M2 & Hi / Merhaba \\
\hline 6 & $03: 41: 43$ & M2 & Özge / Özge \\
\hline 7 & 03:41:48 & IP & All right / Pekala \\
\hline 8 & 03:41:59 & IP & $\begin{array}{l}\text { We are modelling the evaluation process of a new } \\
\text { course proposal / Yeni ders açma önerisi } \\
\text { değerlendirme sürecini modelliyoruz }\end{array}$ \\
\hline 9 & 03:42:19 & IP & $\begin{array}{l}\text { If you are ready, I will describe the process / } \\
\text { hazırsaniz anlatablirim }\end{array}$ \\
\hline 10 & 03:42:30 & M2 & Yes / Evet \\
\hline 11 & 03:42:34 & M1 & OK, we are ready / Ok hazırız \\
\hline 12 & $03: 42: 40$ & IP & OK /Tamam \\
\hline 13 & 03:42:48 & IP & First of all / Öncelikle \\
\hline
\end{tabular}




\begin{tabular}{|c|c|c|c|}
\hline 14 & 03:42:54 & IP & $\begin{array}{l}\text { The lecturer fills in the course proposal form / } \\
\text { Öğretim üyesi ders öneri formunu doldurur }\end{array}$ \\
\hline 15 & 03:43:08 & IP & $\begin{array}{l}\text { Then, sends it to the head of the department / Ana } \\
\text { bilim dalı başkanina iletir }\end{array}$ \\
\hline 16 & 03:43:19 & M2 & $\begin{array}{l}\text { Nurcan, shall we model at the end or while Ahmet } \\
\text { is giving the information? / Nurcan en son mu } \\
\text { modelleyelim yoksa Ahmet anlatirken mi } \\
\text { modelleyelim? }\end{array}$ \\
\hline 17 & 03:43:58 & M1 & $\begin{array}{l}\text { I think we should model while Ahmet is giving the } \\
\text { information / Ahmet anlatıken modelleyelim bence }\end{array}$ \\
\hline 18 & 03:44:12 & M2 & I agree / Bence de \\
\hline 19 & 03:44:19 & IP & $\begin{array}{l}\text { In that case, I will stop now and then to give you } \\
\text { time to model / Ben aralarda durup bekliyorum o } \\
\text { halde size }\end{array}$ \\
\hline 20 & 03:44:32 & M1 & Let's go then:) / Lets go ozaman :) \\
\hline 21 & 03:44:28 & M2 & $\mathrm{OK} / \mathrm{Ok}$ \\
\hline 22 & 03:44:38 & M1 & $\mathrm{OK} / \mathrm{Ok}$ \\
\hline
\end{tabular}

In another interaction episode given in Table 3, the modelers coordinated the work for which they had different objectives to achieve. During the process modeling, M2 had to log off since her whiteboard was frozen for a while. In the meantime (04:06:47 - 04:11:43), M1 continued the modeling on her own. When, M2 returned to the modeling environment, M1 asked M2 to review the changes she had made during M1's absence (Line 8). When M2 saw this request, she read all the information given by the IP and went through the modifications to the model. While M2 was reviewing the model, M1 read the new piece of information (Line 9) and continued modeling. During this time, each modeler independently worked on the same model. After M2 completed her review, M2 read IP's last message (Line 9) and contributed the M1's modeling activity with, "Now, we need a decision element" (Lines 16 and 17), which highlights the need to put a decision model element. This message implied that M2 could now continue to model in collaboration with M1. It is clear that in VMTChat, the team members could easily coordinate their work on the same model. In addition, the modelers were able to switch between cooperative modeling and collaborative modeling modes whenever needed. This means that the modelers could perform individual modeling activities while, at the same time, working collaboratively on the same model.

Table 3 - A snippet of chat communication for coordination

\begin{tabular}{|c|c|c|c|}
\hline Line & Timestamp & $\begin{array}{l}\text { Team } \\
\text { Member }\end{array}$ & Statement \\
\hline 1 & $04: 11: 43$ & M2 & Joins the room \\
\hline 2 & 04:12:06 & M2 & I am back / Geldim \\
\hline
\end{tabular}




\begin{tabular}{|c|c|c|c|}
\hline 3 & $04: 12: 15$ & M1 & $\begin{array}{l}\text { What will the academic committee do with completed form and the } \\
\text { evaluation of the head of the department / Şimdi akademik kurul } \\
\text { aldığ } \text { form ve ABD nin değerledirmesi ile ne yapacak? }\end{array}$ \\
\hline 4 & 04:12:29 & IP & Shall I continue to explain? / Devam edeyim mi anlatmaya \\
\hline 5 & $04: 12: 27$ & M1 & What will the committee do? / komite napacak \\
\hline 6 & 04:12:33 & M1 & Yes / Evet \\
\hline 7 & 04:12:40 & IP & All right / Peki \\
\hline 8 & $04: 12: 48$ & M1 & $\begin{array}{l}\text { Özge, could you check what I have done to see whether there is any } \\
\text { problem with it?/ Özge sen yaptıklarıma bakarmısın sorun var m1 } \\
\text { diye }\end{array}$ \\
\hline 9 & 04:13:10 & IP & $\begin{array}{l}\text { The academic committee assesses the form and decides to approve, } \\
\text { reject or request changes to it / Akademik komite formu alır ve } \\
\text { onay, red veya güncelleme talebi kararlarından birini verir }\end{array}$ \\
\hline 10 & 04:12:58 & M2 & OK / ok \\
\hline 11 & $04: 14: 28$ & M1 & Özge / Özge \\
\hline 12 & 04:14:33 & M1 & $\begin{array}{l}\text { [We use 'organizational unit'] for a committee or a unit / Komite } \\
\text { ve unit olunca }\end{array}$ \\
\hline 13 & $04: 14: 43$ & IP & $\begin{array}{l}\text { I think, we should call this evaluation, too / Buna da değerlendirme } \\
\text { diyebiliriz bence }\end{array}$ \\
\hline 14 & 04:14:51 & M1 & $\begin{array}{l}\text { We are using the 'organizational unit' model element, aren't we? / } \\
\text { organization uniti kullaniyoruz dimi }\end{array}$ \\
\hline 15 & $04: 15: 26$ & M2 & Yes / Evet \\
\hline 16 & 04:16:30 & M2 & Now / Şimdi \\
\hline 17 & $04: 16: 33$ & M2 & We need a decision element / decision var \\
\hline 18 & $04: 16: 37$ & M1 & Yes / Evet \\
\hline
\end{tabular}

The integrated chat component of the system allowed the team members to easily achieve the coordination aspect of collaboration. They were able to send each other instant requests regarding process modeling and make comments on the changes made by other members. For example, "Özge, could you revise this?", "Stop! Ahmet should tell us whether we need to do anything else here, if not, let's skip it", "Özge, could you check what I have done to see whether there is a problem with it?", "No space is left on the screen, let's move onto a new tab".

Group Decision-Making: The interaction analysis showed that the group decision-making characteristic of collaboration could be observed in the synchronous collaborative modeling session in the VMTChat environment. The interaction episode in Table 4 illustrates the decision-making process during which the team members simultaneously worked on the model element. This interaction episode is also interesting since it shows that the modelers differed in terms of their attitudes towards decision-making on the use of the model element. After the IP gave information given about the process (Table 3, Line 9) both modelers deliberated over the use of the correct model element. At this point, M2 asked for IP's opinion to decide on the model element that best represented the case (Line 5). The IP suggested that 
only one of the three options should be selectable at a time (Line 6). In response to IP's message, M1 recommended using 'OR' (Line 7). However, M2 considered that the use of 'XOR' would probably be better (Lines 8 and 9). The further communication between the team members shows that M2 was not sure about the use of the 'XOR' element (Lines 3 and 9) and asked for IP's opinion again whereas M1 immediately accepted M2's suggestion (Line 11). Following the confirmation of 'XOR' by the IP (Line 10), M1 referred to M2 for her approval, which indicates that M1 left the decision-making responsibility to M2 (Lines 12 and 13).

This interaction episode shows that the team members could discuss an issue and easily reach a consensus to create the process model. In addition, this interaction episode indicates that M2 took much more responsibility than M1. Furthermore, M2 seemed to be more motivated than M1 to identify the correct model element. Another important factor affecting the performance of BP Modeling in this process was found to be IP's model reading capability.

\section{Table 4 - A snippet of chat communication for group decision-making}

\begin{tabular}{|c|c|c|c|}
\hline Line & Timestamp & $\begin{array}{l}\text { Team } \\
\text { Member }\end{array}$ & Statement \\
\hline 1 & $04: 16: 54$ & M2 & An event comes after this / Bundan sonrasına bir event gelecek \\
\hline 2 & 04:17:17 & M2 & $\begin{array}{l}\text { Then, this event branches with XOR / Sonra o event xor ile } \\
\text { dallanacak }\end{array}$ \\
\hline 3 & 04:17:22 & M2 & $\begin{array}{l}\text { Either that or with 'OR', I am not sure / yada or da olabilir emin } \\
\text { degiilim }\end{array}$ \\
\hline 4 & 04:17:54 & M1 & I will put 'OR' / or koyuyorum \\
\hline 5 & 04:18:41 & M2 & $\begin{array}{l}\text { Dear referee Ahmet, what do you think about this? / Sayın bilir } \\
\text { kişi Ahmet bey sizin bu konudaki fikriniz nedir? }\end{array}$ \\
\hline 6 & 04:19:32 & IP & $\begin{array}{l}\text { Only one of the three decisions should be taken / Yani } 3 \\
\text { karardan sadece biri verilmeli }\end{array}$ \\
\hline 7 & 04:19:41 & M1 & OR / Veya \\
\hline 8 & 04:19:52 & M2 & Yes / evet \\
\hline 9 & 04:19:57 & M2 & $\begin{array}{l}\text { In that case, it should probably be XOR / O zaman xor olmali } \\
\text { galiba }\end{array}$ \\
\hline 10 & 04:20:28 & IP & $\begin{array}{l}\text { I agree, it should be XOR because two decisions cannot be } \\
\text { taken at the same time / Bence de xor, çünkü iki karar çıamaz } \\
\text { oradan }\end{array}$ \\
\hline 11 & $04: 20: 16$ & M1 & Let's use XOR / xor olsun hadi \\
\hline 12 & $04: 20: 25$ & M1 & Do you approve XOR? / Onaylandın mı xor \\
\hline 13 & 04:20:35 & M2 & Yes I do / evet onayliyorum \\
\hline
\end{tabular}

Awareness: The interaction analysis and eye-tracking data showed that the team members were able to access and use the same objects on the shared whiteboard, read all the messages sent by other team members and view the latest version of the process model. The awareness aspect of collaboration was also supported by the use of different colors to represent each team 
member and the notifications about the person writing the message. In addition to these system features, the reference tool played an important role in preventing any communicational complexities and awareness problems during the interaction between the team members and regarding the use of the shared whiteboard (Stahl et al., 2006). The following examples of interaction show how the reference tool made the communication much easier and increased mutual intelligibility among the team members.

As shown in Table 5, after the IP gave a piece of information about the process (Line 4), M1 asked a question, "We link to the top from here, is this right?" (Line 9) and used the reference tool to point to 'here' in her message. The eye-tracking data of M2 showed that she read the message sent by M1 and followed the reference link to see the related model element (Figure 4). After M2 implemented the event element, she responded to the question with a message (Line 11).

A similar use of the reference tool was seen many times throughout the process modeling (see Lines 12, 13 and 16), in which the modelers referred to the model elements on the whiteboard only using the deictic pronouns such as 'here' and 'this'.

Table 5 - A snippet of chat communication for awareness

\begin{tabular}{|c|c|c|c|}
\hline Line & Timestamp & $\begin{array}{l}\text { Team } \\
\text { Member }\end{array}$ & Statement \\
\hline 1 & $04: 22: 21$ & M1 & Now, Ahmet / Şimdi Ahmet \\
\hline 2 & $04: 22: 26$ & M1 & $\begin{array}{l}\text { Is it [the process] finished once it is approved? / Onaylayınca } \\
\text { bitiyor mu }\end{array}$ \\
\hline 3 & $04: 22: 31$ & IP & Nothing else / Hayır \\
\hline 4 & $04: 22: 33$ & IP & $\begin{array}{l}\text { If there is a request for changes, then the process returns to the } \\
\text { beginning / Güncelleme talebi geldiyse süreç başa dönüyor }\end{array}$ \\
\hline 5 & $04: 22: 49$ & IP & $\begin{array}{l}\text { If it [the course] is approved, the Institute Committee makes a } \\
\text { final evaluation / Onay ise Enstitü Kurulu son bir değerlendirme } \\
\text { yapıyor }\end{array}$ \\
\hline 6 & $04: 22: 58$ & M1 & Does the process start again from the top? / En başa mi? \\
\hline 7 & 04:23:09 & IP & $\begin{array}{l}\text { Also, the institute secretary adds the new course to the course } \\
\text { catalogue in OIBS / ve enstitü sekreteri OIBS'de yeni dersi ders } \\
\text { kataloğuna ekliyor }\end{array}$ \\
\hline 8 & $04: 23: 44$ & IP & $\begin{array}{l}\text { OIBS is the student information system / OIBS bizim öğrenci } \\
\text { işleri bilişim sistemimiz }\end{array}$ \\
\hline 9 & 04:25:09 & M1 & $\begin{array}{l}\text { We link to the top from here, is this right? / Burdan başlangıca } \\
\text { ok götürücez dimi }\end{array}$ \\
\hline 10 & $04: 25: 39$ & M2 & Yes / Evet \\
\hline 11 & $04: 25: 47$ & M2 & $\begin{array}{l}\text { These arrows cannot be bent, so they don't look good. But we } \\
\text { cannot do anything about it / Burdaki oklar kıvrılmadığı için } \\
\text { kötü gözüküyor ama başka çare yok }\end{array}$ \\
\hline
\end{tabular}




\begin{tabular}{|c|c|c|c|}
\hline 12 & $04: 26: 11$ & IP & $\begin{array}{l}\text { Shall we call this 'Request for Change'? / Bunun adı güncelleme } \\
\text { isteği olabilir mi? }\end{array}$ \\
\hline 13 & $04: 26: 27$ & M2 & What about OIBS for this? / Bu oibs olsun mu? \\
\hline 14 & 04:27:06 & M1 & OK $\odot:$ / olsun :) \\
\hline 15 & $04: 27: 12$ & M1 & It is too similar / Çok benziyo \\
\hline 16 & 04:27:55 & M2 & $\begin{array}{l}\text { I made a joke. This should be OIBS / Şaka yaptım bu oibs } \\
\text { olcakmış }\end{array}$ \\
\hline
\end{tabular}

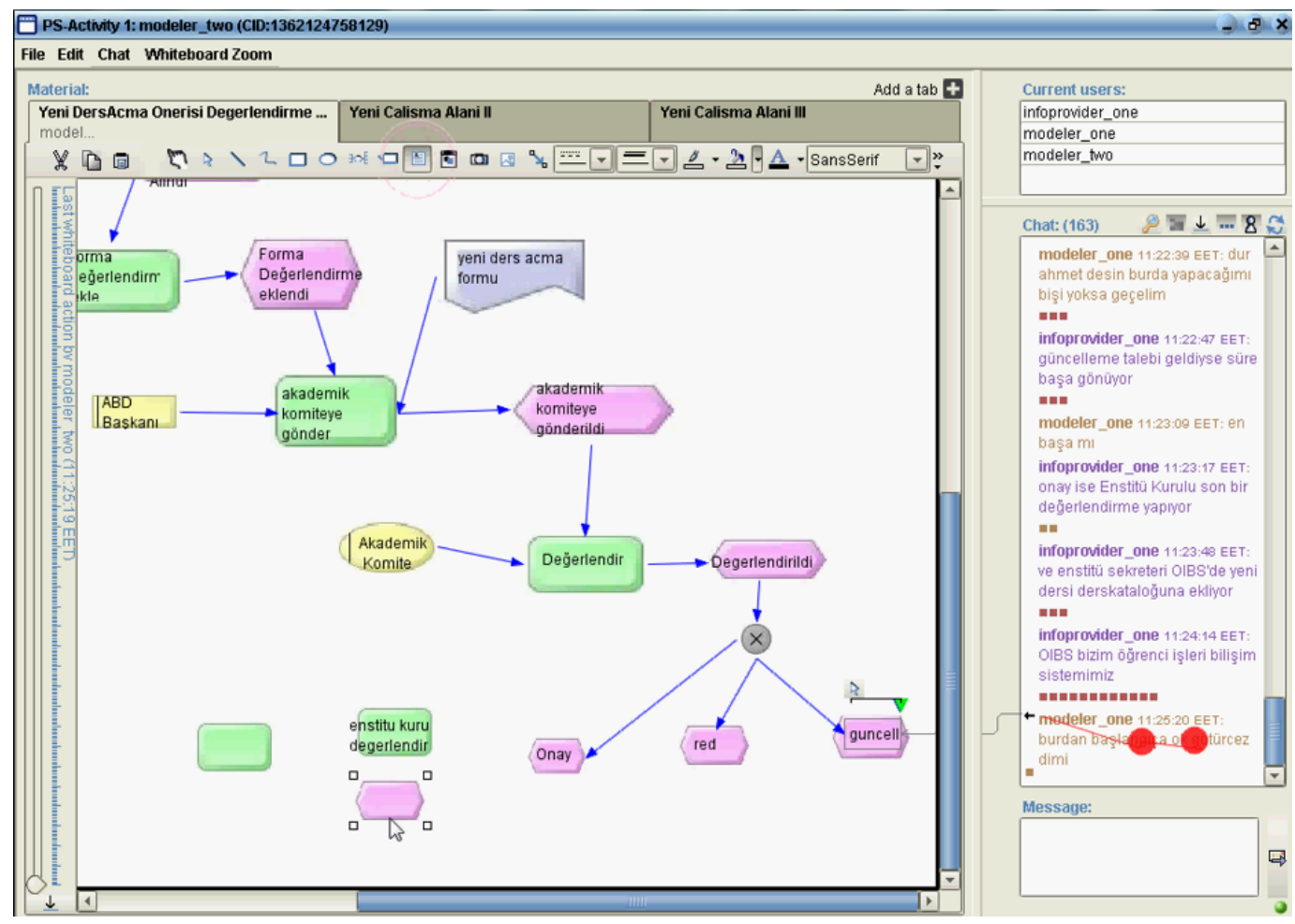

Figure 4 - Use of the Reference Tool on the Whiteboard (Red dots over the chat window represents the eye movements of the modeler who was reading the message including a referential link to the whiteboard.)

It was observed that the reference tool supported the awareness aspect to reduce possible communication complexities by referring not only to the whiteboard area, but also to the chat window. As shown in Figure 5, M2 sent the message, "That's it" pointing to the message sent by the IP at 11:23:48. The reference link not only attracted the attention of M1, but also simplified M2's work since she did not have to rewrite the message. 


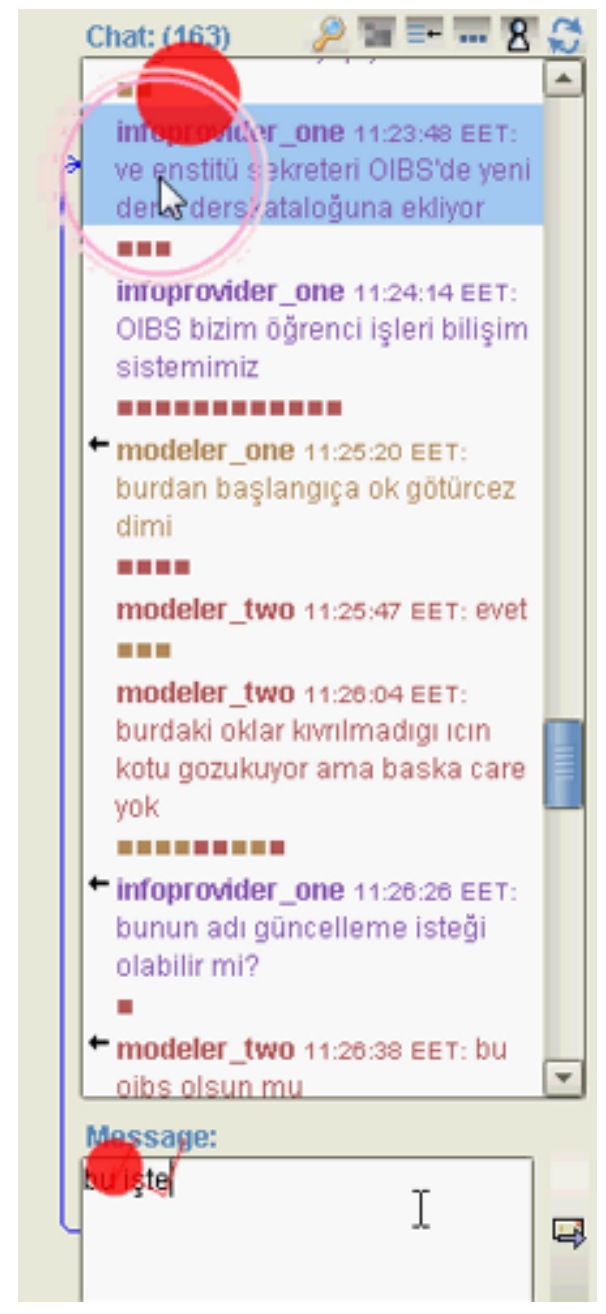

\section{Figure 5 - Use of the Reference Tool in the Chat Window}

It is clear that the reference tool facilitated the communication and increased mutual intelligibility by making the team members aware of the objects on the whiteboard and the messages in the chat window. The team members could point to the model elements only by using the expression, 'this' rather than repeating the long names of the model elements.

Communication: The communication aspect of collaboration was supported throughout the modeling session with the integrated chat window shown in Figure 6. The team members were able to send and receive messages using this component. The chat window provided an interactive discussion platform also supporting the awareness aspect of collaboration. The team members were notified when one of their peers was writing a message. In addition, the active team members were shown in the current users window and their messages were displayed in the chat window using different colors to increase their readability. Furthermore, the referencing function of the system could be used on the chat messages. Figure 6 illustrates the chat window of the system. 


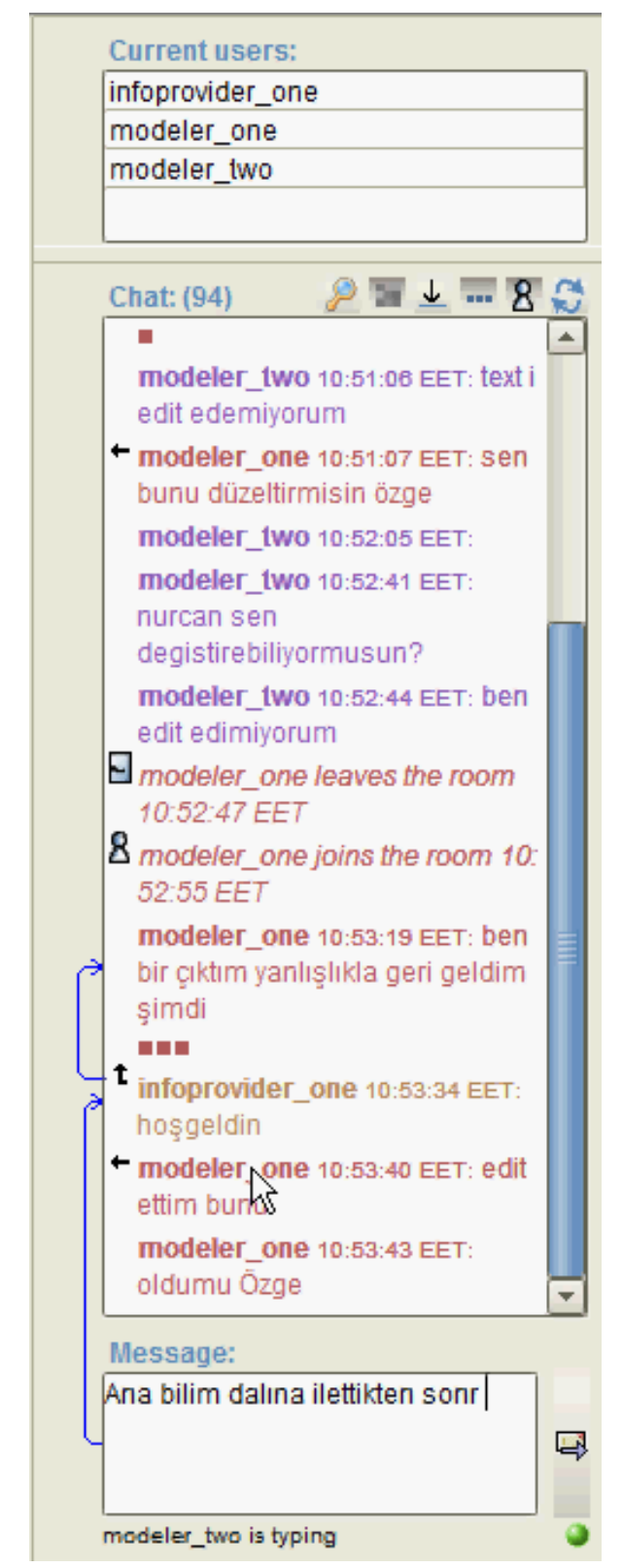

Figure 6 - Chat Window of VMTChat (The blue arrows represent referential links added by the users)

Team-Building: The roles of the team members were assigned prior to the modeling session. The system does not have any features to restrict the responsibilities of the team members and their access rights on the shared whiteboard. However, interaction among the team members showed that the team members were successful in performing their roles throughout the modeling activity. The IP informed the modelers about the business process and the modelers performed the modeling activity based on this information. The IP and modelers were able to conduct elicitation, formalization validation and verification phases of $\mathrm{CBPM}$ as necessary. The interaction analysis suggested that the team members were self-motivated to conduct their 
responsibilities; therefore, they did not have any problems due to the system's limitation to restrict user permissions according to their roles.

\section{Observation of BP modeling phases on VMT Chat}

The interaction analysis showed that the VMTChat platform was capable of supporting all five aspects of collaboration during the synchronous process modeling activity. Therefore, the BP Modeling phases were examined in a system involving all aspects of collaboration together.

The collaborative BP Modeling activity was performed with iterations (Figure 7) including elicitation, formalization, and validation and verification phases. The IP gave information about the process four times, which means that the elicitation phase of the BP Modeling was observed four times (see red points in Figure 7). This indicates that the modeling activity was performed with four iterations. A detailed examination of each iteration shows that the IP gave brief information about the process, then the modelers initiated the formalization phase. Throughout this phase, the IP performed validation on the model and warned the modelers about incorrect representations and complex sections. The modelers also verified their actions during the formalization phase. It was observed in the iterations that there was a strict boundary between elicitation and the other phases of BP Modeling. However, formalization, validation and verification phases were conducted concurrently. In addition, in the overall modeling activity some iterations overlapped although they were few in number. Moreover, there were less elicitation activities in the later periods of the modeling session whereas the frequency of validation and verification activities increased close to the end of the session.

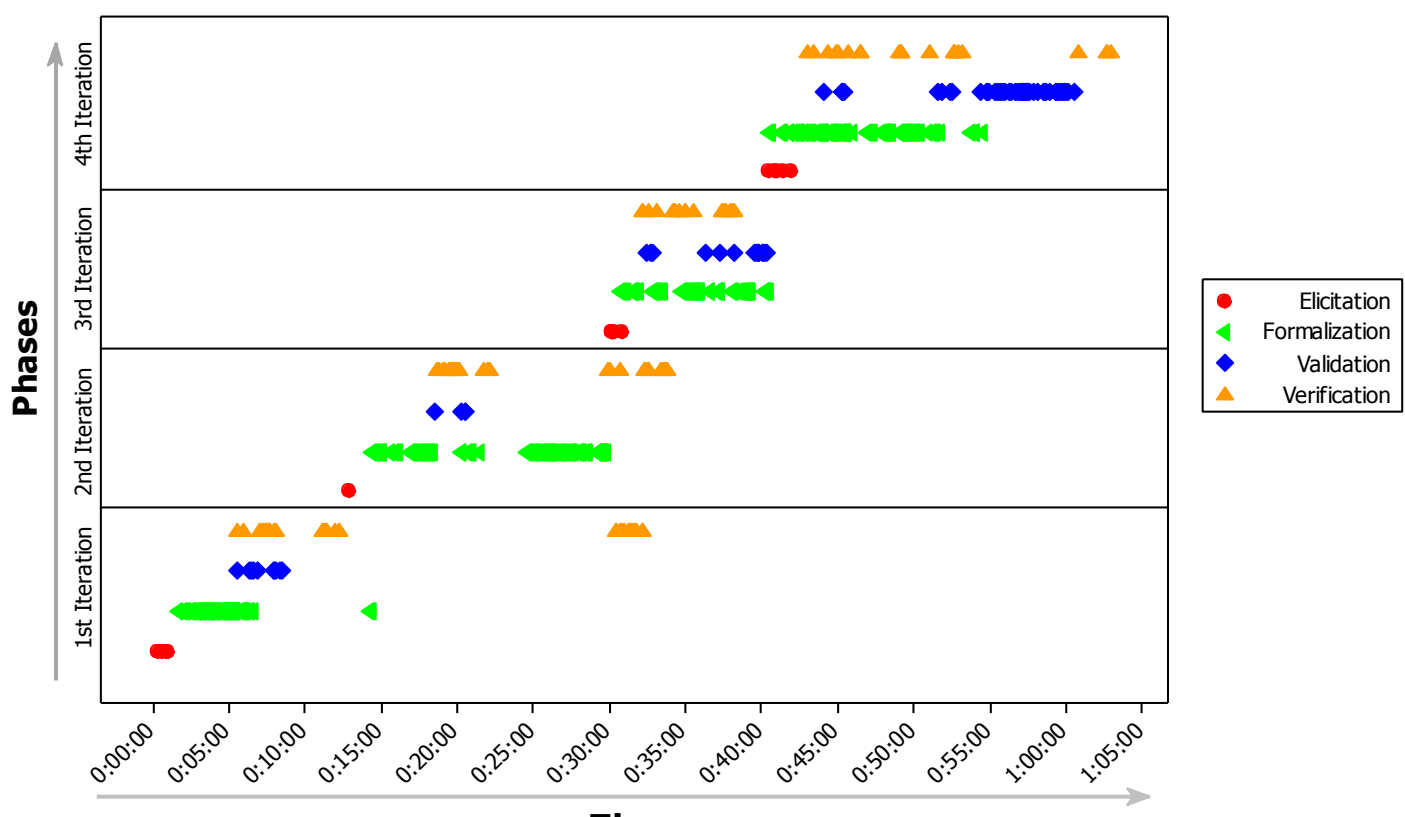

Time

Figure 7 - Temporal Distribution of BP Modeling Phases in VMTChat

http://www.ajit-e.org/?menu=pages\&p=details_of_article\&id=349 


\section{ARISalign: Interaction analysis based on the aspects of collaboration}

Table 6 presents the whole interaction episode for the synchronous collaborative modeling session conducted in ARISalign.

Table 6 - Chat communication conducted in ARISalign

\begin{tabular}{|c|c|c|c|}
\hline Line & Timestamp & $\begin{array}{l}\text { Team } \\
\text { Member }\end{array}$ & Statement \\
\hline 1 & 1:05 PM & IP & Hi guys, here we go. / Merhaba arkadaşlar, başliyoruz. \\
\hline 2 & 1:08 PM & IP & Are you there? / Geldiniz mi? \\
\hline 3 & 1:09 PM & M2 & I am here / Geldim \\
\hline 4 & 1:10 PM & IP & $\begin{array}{l}\text { Welcome Özge, we will start when Nurcan arrives / } \\
\text { Hoşgeldin Özge, Nurcan da gelsin başlayalım }\end{array}$ \\
\hline 5 & 1:13 PM & M2 & Ok, I am waiting / ok bekliom \\
\hline 6 & 1:19 PM & M1 & Hey there / Heyoo \\
\hline 7 & 1:54 PM & IP & $\begin{array}{l}\text { Let's start again, are you ready Özge? / Tekrar başliyoruz, } \\
\text { hazır misın Özge? }\end{array}$ \\
\hline 8 & 1:55 PM & M2 & I am ready / Hazırım \\
\hline 9 & 1:56 PM & M1 & I am in, too / ben de varim \\
\hline 10 & 1:56 PM & IP & $\begin{array}{l}\text { All right; the examination committee purchases the } \\
\text { materials. The committee prepares a receipt and a } \\
\text { certificate of acceptance for the received purchased } \\
\text { materials. / Peki; Muayene kabul komisyonu malzemeyi } \\
\text { teslim alır. Alınan malzeme için fatura ve muayene kabul } \\
\text { tutanağ düzenler }\end{array}$ \\
\hline 11 & 1:57 PM & IP & Welcome to you, too / Sen de hoş geldin \\
\hline 12 & 2:00 PM & M2 & $\begin{array}{l}\text { Nurcan, can you see the task that I have just created / } \\
\text { Nurcan görebiliyon mu koyduğum taski? }\end{array}$ \\
\hline 13 & 2:02 PM & M2 & $\begin{array}{l}\text { I have done what you said, you can continue / Bu } \\
\text { dediklerini yaptım devam edebilirsin }\end{array}$ \\
\hline 14 & 2:02 PM & IP & $\begin{array}{l}\text { Who is editing the process now? / Şu an kim edit ediyor } \\
\text { süreci? }\end{array}$ \\
\hline 15 & 2:02 PM & M1 & $\begin{array}{l}\text { Özge, first we need to create the roles; then add the } \\
\text { activities under these roles / Özge, önce rolleri koyup içine } \\
\text { aktivite koyacaktık }\end{array}$ \\
\hline 16 & 2:04 PM & M2 & $\begin{array}{l}\text { I performed the last editing, I am waiting for your } \\
\text { progress. I have added } 2 \text { tasks / En son ben ettim, devam } \\
\text { etmeni bekliyom. } 2 \text { tane task koydum }\end{array}$ \\
\hline 17 & 2:04 PM & IP & $\begin{array}{l}\text { Then, the movable records control officer transfers the } \\
\text { purchased materials to the related people by preparing a } \\
\text { debit entry. He prepares a movable transaction receipt for } \\
\text { each debit entry / Daha sonra taşınır kayıt kontrol yetkilisi } \\
\text { alınan malzemeyi kişiler üzerine zimmetler, bunun için }\end{array}$ \\
\hline
\end{tabular}


2:07 PM

IP zimmet kaydı düzenler, her zimmet kaydı için bir taşınır işlem fişi oluşturulur

Özge, I have assigned the material receiving committee as a role / Özge muayene kabul komisyonunu rol olarak atadim

The documents produced for the activity of "receiving the material" are: receipt and certificate of acceptance / "alınan mazleme icin kabul tutanagı duzenlenir " isimli aktivite ile ilgili olarak düzenlenen belgeler: fatura ve malzeme kabul tutanağ 1

It seems like Nurcan is editing, so I am just looking. But I can't see it / Nurcan edit ediyor gözüküyor o yüzden suan bakıyorum sadece. Gerci göremiom

Sorry about that, it [the system] assigned editing to me. I have closed it now /Kusura bakmayın bana vermiş editing'i. kapattım şimdi

Who is editing?? Nurcan, you seem active but you haven't put anything in, either / Kim edit ediyor?? Nurcan sen gozukuon ama sende bisı koymuonnnn

Come on friends, model this / Hadi arkadaşlar, modelleyin şunu

Nurcan, I assigned it to you / Nurcan sana devrettim Who is modeling? Is she really modeling? It is not certain. It is just waste of time. We cannot even do such a small process / Kim modelliyor, gerçekten modelliyor mu hiç belli değil. zaman kaybı sadece. bu kadar küçük bir süreci bile yapamadik

I added what I have understood, could you check it? / Ben anladıklarımı ekledim bir kontrol edermisiniz?

Guys, I am leaving now. Please check the model one last time / Ben çıkıyorum arkjadaşlar. Siz de modeli son kez gözden geçirin lütfen

Guys; when a debit entry is created, the system also needs to create a movable transaction receipt at the end of them model/ Arkadaşlar; Zimmet kaydı oluştururken bir de taşınır işlem fişi (TIF) oluşturması gerekiyor en sonda Yes guys, I am waiting for you. Are you doing what I last said / Evet arkadaşlar sizi bekliyoruz. Yapıyormusuz son söylediğimi?

That message didn't arrive. It is not possible to model with this program, I can't interact. I want to model but I can't because it is always in-use mode / Bana hic msj filan gelmio. $\mathrm{Bu}$ programla modellemek mumkun degil. 


\begin{tabular}{llll}
\hline & & & \\
& & & \\
& & & \\
& & & \\
& & & \\
& & &
\end{tabular}

Coordination: Unlike the modeling experience in the VMTChat environment, the participants did not discuss the coordination of the modeling process in ARISalign. This was probably because they had already gained experience in the first collaborative modeling session. It was observed that the team members coordinated the modeling activity in stages as in the VMTChat activity. This means that after the IP gave brief information about Process II, the modelers created the model and then discussed the validity of the model. However, the interaction of the team members showed that they could not efficiently perform modeling using this approach. In ARISalign, the discussion board and the whiteboard for modeling are on different pages. Therefore, the modelers had difficulty following the messages sent by the IP and perform the modeling concurrently. The eye movements of M2 showed that she read the information given by the IP several times, and then switched to the whiteboard page to draw the model. After M2 completed a task, she returned to the discussion board to read the information again. Although M2 had already read the information carefully first time, she could have forgotten the details when switching between the pages. This indicated a weakness in the system design in terms of facilitating coordination between the communication channel and the modeling area. Therefore, the team members could not effectively coordinate the modeling process.

Communication: The communication aspect of collaboration was supported with the discussion board. Team members could create a new topic and sustain their communication using this platform. However, the communication platform and the modeling area of the system were on two different pages. The interaction analysis showed that the team members had difficulties in communicating with each other due to the system design. The eye movements of the modelers showed that they often had to switch between the discussion board and the whiteboard area to see whether there was a new message. An example of this is M2's message, “That message didn't arrive. It is not possible to model with this program, I can't interact. I want to model but I can't because it is always in-use mode" (Line 30).

In addition, the team members experienced technical problems in the communication platform of ARISalign. The system could not immediately display the messages on the discussion board. This technical problem caused communication complexities since team members ended up not reading some of the messages in the correct order. For example, M2 sent the message, "Özge, first we need to create the roles; then add the activities under these roles" (Line 15) to verify her modeling activity. However, M1's message was displayed on M2's discussion board two minutes later only after M2 refreshed the page. 
Awareness: The following awareness problems in the system can be listed as obstructing efficient collaboration among team members. The system did not give any notifications about the new messages on the discussion board or the availability of the whiteboard area for modeling. Due to these limitations, the users often had to switch between the discussion board and whiteboard. This frequent navigation between pages distracted the team members and caused problems in process modeling. Besides, the team members were not made aware whether the messages they sent were read by the other team members. Moreover, the modelers had to wait for each other to complete the modifications to the modeling without knowing what changes were being made by the other person or how long it would take her to complete the action.

Team Building: The system was capable of building a team and assigning different roles to the team members such as project owner, contributor, administrator and reviewer. The current modeling experience required an IP that would own the business process and two modelers, who were responsible for converting the process into a formal representation. Therefore, the IP was assigned the project owner role and the modelers were given the project contributor role. Both the IP and modelers could use the shared whiteboard. The interaction analysis showed that the team members did not had any difficulties building the team and carrying out their responsibilities.

Group Decision-Making: The interaction analysis of the synchronous process modeling activity using ARISalign showed that the team members had poor communication and interaction with each other. Therefore, they could not achieve a sufficient level of maturity in their communication to discuss an issue in detail to arrive at a decision. The members merely tried to communicate with each other throughout the session. Therefore, the team could not achieve the group decision-making aspect of collaboration in this session. In summary, reaching a decision requires good communication and interaction, a process that involves proposing and evaluating alternatives and making choices. Poor communication and interaction between team members pose an obstacle to initiating discussions and reaching a consensus.

\section{Observation of BP modeling phases on ARISalign}

The interaction analysis showed that the ARISalign platform was not effective in supporting coordination, communication, awareness and group decision-making aspects of collaboration in synchronous collaborative process modeling. The BP Modeling phases were also examined to see how they unfolded in the ARISalign environment.

In this case study, process modeling was not performed with iterations involving the elicitation, formalization, validation and verification phases of BP Modeling. Therefore, the modeling process could not be performed with small manageable units. Moreover, the BP Modeling phases could not be performed concurrently; therefore, the boundaries between these phases were more distinct as shown in Figure 8. The IP started the first elicitation phase by giving brief information about the process. Then, the modelers initiated the formalization phase. When the formalization phase was completed, verification was performed on the model. Then, the IP provided new information about the process and started the second 
elicitation phase. Despite the new information, team members continued to perform verification and validation phases for the modeling activities performed in the first elicitation phase. Then, formalization was performed for the second elicitation phase. Once the formalization phase was completed, verification was performed again for the first elicitation phase. Finally, modeling was completed with a general validation and verification of the model.

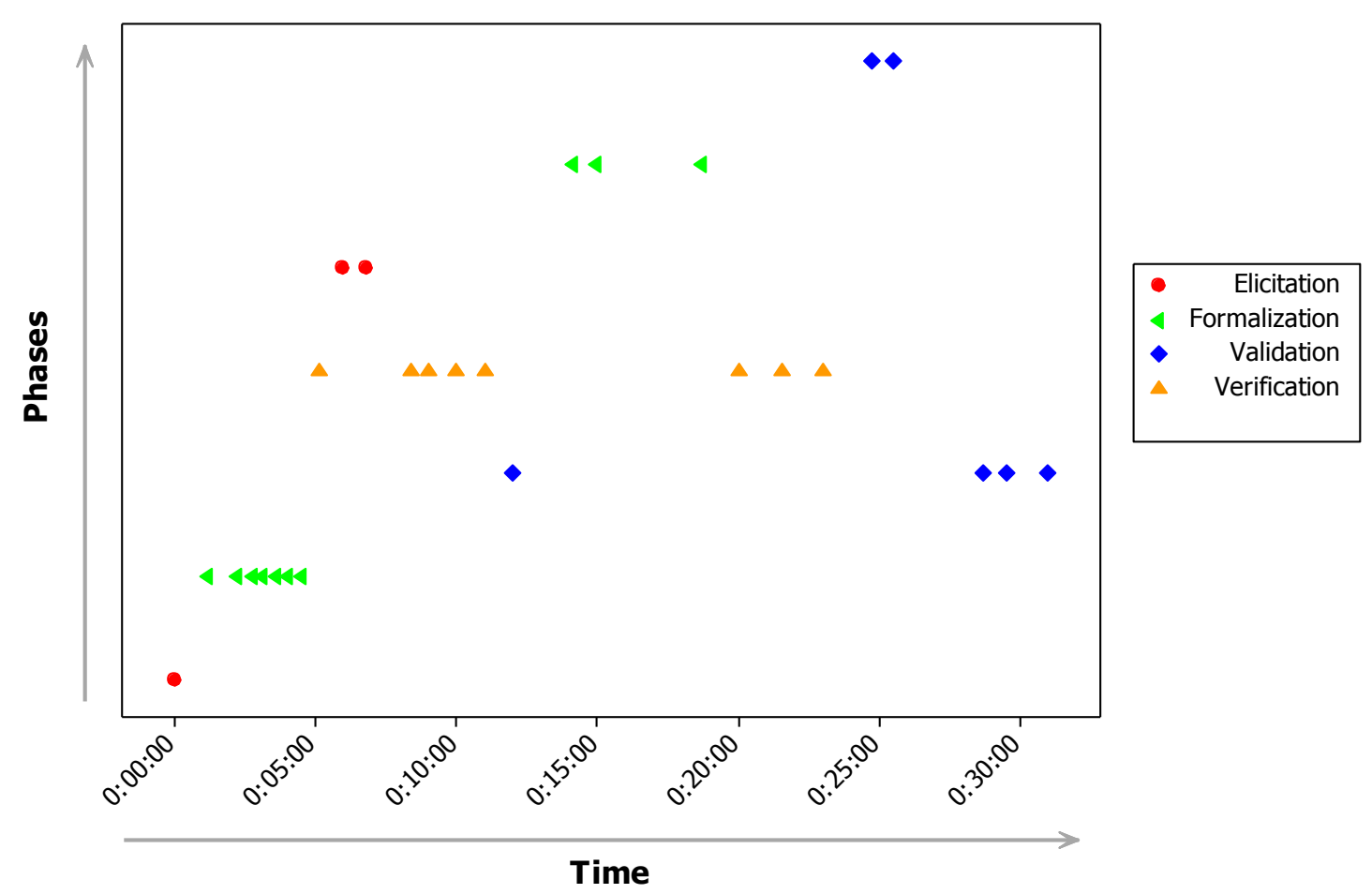

Figure 8 - Formation of BP Modeling Phases in ARISalign

\section{Discussion}

This study aimed to reveal how different interaction methodologies qualitatively affect synchronous process modeling by examining the coordination, communication, awareness, group decision-making and team-building aspects of collaboration. For this purpose, VMTChat and ARISalign were chosen as different CSCW interaction methods with different interface designs. In the VMTChat platform, the stakeholders can use the whiteboard area concurrently. However, in ARISalign, only the active user, who first accesses the model, has the right to edit it, and the other users have to wait for the active user to complete his/her editing on the whiteboard. Furthermore, the results of the current study showed that the interaction designs of the systems affected the occurrence and the organization of the BP Modeling phases. Based on these observations certain suggestions can be made regarding the design of CSCW systems that aim to support cBPM processes online. 
The interaction analysis methodology was used to evaluate both platforms' appropriateness for CSCW activities based on the sequential unfolding of the group members' actions captured in screen-recordings. It was clear that VMTChat supported the five aspects of collaboration and promoted interactivity among the team members. Modeling with VMTChat allowed the team members to coordinate the modeling process through discussions throughout the modeling activity. In addition, the system notified the team members of the new messages in the chat window and the modeling activities in the shared work area. Furthermore, the team members were able to communicate instantly whenever needed without experiencing any communicational complexity such as problems with the communication flow or misunderstandings due to the content of the messages. Before the modeling sessions, the team members were assigned the IP and modeler roles and throughout their interaction, they were able to perform their responsibilities and share their work when required. In addition, it was observed that the team members could easily discuss the related issues and reach a group decision regarding how to resolve them. However, the team members encountered a system error, in which the shared whiteboard suddenly froze. Therefore, they could only continue their modeling activity after several attempts of reconnecting and logging into the system. Apart from this instance, the team members were generally satisfied with the VMTChat environment, which was successful in supporting all the five collaboration aspects.

The ARISalign system, on the other hand, was not as efficient as VMTChat in supporting the collaboration aspects; particularly coordination, communication and awareness. The team members tried to coordinate the collaborative modeling process based on their previous experience in the VMTChat environment. However, they had difficulty coordinating and managing the modeling process due to the system's insufficient support for communication and awareness. In addition, since the platform failed to provide synchronous communication, the team members had difficulties making sense of each other's messages. Furthermore, the team members were not made aware of the messages on the discussion board and activities performed in the shared working area. This led to ineffective communication flow and poor coordination in terms of the messages and the modeling activities. As in the previous modeling experience, the team members were assigned the IP and modeler roles that involved different responsibilities; however, they could not interact effectively to achieve an appropriate division of labor. In addition, the interaction of team members could not reach a sufficient level of maturity to achieve the group decision-making aspect. The interaction analysis showed that the team members complained about ARISalign because they could not perform the modeling concurrently or communicate with each other efficiently. Therefore, they lost interest and wanted to leave as soon as possible. Furthermore, all the team members agreed that they did not want to use this system again for process modeling since they spent too much time on modeling such a small process (See Lines 23, 25, 30 and 31 in Table 6).

It was observed that different interaction designs had a different impact on the BP Modeling phases. In the VMTChat environment, process modeling was performed with iterations that started with the transfer of a piece of information, called elicitation followed by formalization, validation and verification phases. This modeling approach allows working with more manageable units when performing modeling. In VMTChat, although iterations sometimes 
overlapped, a new iteration was initiated once one was completed. The BP Modeling phases went parallel in the iterations. VMTChat was found successful in supporting the aspects of collaboration during the interaction among participants. This effective interaction allowed the team members to easily manage the cBPM process. The team members could also clearly segment the process using iterations when simultaneously carrying out the BP Modeling phases. However, in ARISalign, the cBPM process could not be managed effectively. The interaction analysis showed that the team members could not discuss the process in detail due to the difficulties involved in the communication channel and the modeling area. The team members intended to perform modeling with manageable units similar to VMTChat; however, they could not use an iterative model due to the system limitations regarding interaction and communication. A similar situation was observed in the BP Modeling phases. A new phase could not be started before the previous phase was completed. In addition, the sequence of the phases did not conform to a logical order, which resulted in confusion about the phases.

\section{Suggestions on system designs for effective collaboration in cBPM practices}

The interaction analysis performed on different methodologies demonstrated the effects of different features on the five aspects of collaboration. Based on these results, the following suggestions can be made to achieve a system design that adequately supports each of the five aspects.

To support the coordination aspect in cBPM;

- The communication window and the modeling area should be included in the same interface to easily coordinate the messages and the model elements. If the communication and modeling components of the systems are on different pages, then the modelers have to switch between the pages. This frequent navigation between the pages of the system causes problems such as losing interest in the process and not being able to remember the given information when trying to find the right page.

- The modelers should be able to change the status of the modeling area to 'in-use' when required. If the system does not support this function, the modeler loses interest when waiting for the others to complete their editing.

- The system should be able to immediately display the changes that are applied.

- The modeling environment should support both cooperative and collaborative modeling which means the modelers should be able to work both on the same model element and different parts of the model.

To support the communication aspect in cBPM;

- The system should be supported with a communication tool, which enables the team members to send instant messages when required. 
- In long conversations, chat communication brings some limitations. For example, communicating via typing is time consuming. In addition, in instant messaging, short and rapid messages are posted during the communication on the chat environment and a single message spread over multiple postings (Strijbos, 2009; Zemel et al., 2007). In the long conversations, it is difficult to follow the messages that are linked with each other. In order to reduce the communicational complexities that arise from the nature of chat communication, the system should also be supported with video conferencing.

Awareness is also critical for the success of the communication and coordination aspects of collaboration; therefore; the communication tools and shared whiteboard of the systems should have the following features to support awareness;

- The system should have a current user window to display all the active users.

- In the communication window, the users and their messages should be easily identifiable. Different colors can be used to differentiate between the messages of different users.

- The system should display a notification when a user is writing a message.

- The system should notify the users of new messages and when their messages have been read.

- The communication platform should be error-free, which means that messages should be displayed on the other participants' screen in real-time and in the correct order.

- The use of the reference tool in VMTChat increases the traceability of the messages in the chat window and reduces the users' workload. Such a feature allows the participants to follow the messages easily, relate the messages to the relevant model components, and send shorter messages without having to repeat what had already been written in a previous message. Therefore, providing support for referencing in the communication tool of the system may significantly improve the intelligibility of the unfolding modeling activity.

- The system should be able to establish a connection between messages written in the chat window and the modeling area. This easy referencing enables the participants to engage in rapid and understandable communication since they do not have to write the whole name of the model elements or spend time on searching the whole model to find the related element.

- The system should allow the team members to know which model element has been created by whom to increase personalized communication.

- The system should allow the users to be aware of the actions and all sorts of editing performed on the whiteboard and the model, and display a notification when a modeling activity is being performed. 
- Business process models can include complicated structures and connections, which makes it technically difficult to give users full shared access to the model, since editing performed in one part of the model by one team member may have implications on another part of the model accessed by another member. Such complications may force CSCW designers to restrict simultaneous access to the model and implement a turnbased access mechanism. In that case, the system should at least provide a time-out mechanism so that one user cannot indefinitely hold access to the shared model, and communicate this information on the shared screen as an awareness message.

The system should provide an effective environment to support the coordination, communication and awareness aspects since group decision-making relies on these aspects to allow the participants to effectively discuss an issue and reach a consensus. In addition to these, the systems should have the following feature to support group decision-making.

- When the team members cannot discuss an issue in detail or select an appropriate model element to reflect the process information correctly, they may not be able to reach a consensus on that issue immediately. To allow the team members to easily refer back to this problematic issue at a later time, the related model element can be signed as 'unresolved'.

User permissions in the system should be flexible enough to fulfill members' requirements when performing their responsibilities. To support the Team Building aspect in CBPM, the following suggestions can be made regarding the permissions that can be extended to team members that have the IP or modeler roles;

- All the modelers should be able to edit the model at the same time and see the performed changes immediately. The latest version of the model should be available to the IP and modelers when they need, without having to wait for the completion of ongoing actions.

- The IP should be able to access and refer to the model when discussing it.

- It should be possible to lock certain parts of the model for editing since the modelers may want to change their working approach from collaborative to cooperative.

\section{Limitations}

The study has inevitably some limitations given the complexities involved with designing CSCW systems that aim to support cBPM processes. First, the study was conducted with two case studies with purposive sampling. Although the participants of the study had adequate expertise to perform BP modeling, the number of cases with different participants could be increased to enhance the generalizability of the results. Our main motivation in this detailed, small-scale study was to identify key requirements for successfully supporting cBPM processes online based on empirical insights grounded on a close analysis of the users' actions 
in situ. Secondly, eEPC and BPMN were used in the BP Modeling sessions, which might cause different levels of mental effort from the formal language point of view. Therefore, a future study may focus on the implications of using other modeling languages for a more systematic comparison of different modeling formalisms. The processes under consideration might have an impact on the mental effort of the participants and the duration of the sessions. In this study, we mainly focused on how participants organized their work while collaborating at a distance using the features provided by two different CSCW systems. The systems were selected as they offer various different coordination, communication, awareness, decision making and team-building features typically found in many existing CSCW systems. Therefore, measures such as task completion time or performance evaluation were not our primary focus. A study that aim to systematically explore such aspects in a more experimental setup should carefully consider using processes that are balanced in complexity so that the model co-constructed by different groups could be comparable in terms of measures such as accuracy, completion time, and model complexity.

\section{KAYNAKÇA}

Baghaei, N., Mitrovic, A., \& Irwin, W. (2007). Supporting collaborative learning and problem-solving in a constraint-based CSCL environment for UML class diagrams. International Journal of Computer-Supported Collaborative Learning, 2(2-3), 159-190. doi: 10.1007/s11412-007-9018-0

Bannon, L. \& Schmidt, K. (1989). CSCW: Four characters in search of a context. In Proceedings of the first European conference on computer support for cooperative work (ECSCW '89) (pp. 358372). Gatwick, London. Retrieved from http://dl.acm.org/citation.cfm?id=117731

Basheri, M. (2010). Collaborative learning of UML-State diagrams using multi-touch technology. Retrieved from 0.1.1.454.4993\&rep=rep1\&type $=$ pdf

Cherry, S., \& Robillard, P. N. (2008). The social side of software engineering-A real ad hoc collaboration network. International Journal of Human-Computer Studies, 66(7), 495-505. doi: 10.1016/j.ijhcs.2008.01.002

Davis, R., \& Brabänder, E. (2007). ARIS design platform: getting started with BPM. London: SpringerVerlag.

Dollmann, T., Houy, C., Fettke, P., \& Loos, P. (2011). Collaborative business process modeling with comomod-a toolkit for model integration in distributed cooperation environments. In Reddy $\mathrm{S}$, Tata S (eds) Proceedings of the 20th IEEE international conference on collaboration technologies and infrastructures. IEEE international workshops on enabling technologies: infrastructure for collaborative enterprises (WETICE-2011) (pp. 217-222). Paris. Retrieved from http://ieeexplore.ieee.org/document/5990030/

Dourish, P., \& Bellotti, V. (1992). Awareness and coordination in shared workspaces. In Proceedings of the ACM CSCW Conference on Computer-Supported Cooperative Work (pp. 107-114). Toronto, Ontario, Newyork: ACM. Retrieved from http://dl.acm.org/citation.cfm?id=143468 
Forster, S., Pinggera, J., \& Weber, B. (2013). Toward an Understanding of the Collaborative Process of Process Modeling. InProceedings of CAiSE Forum (pp.98-105). Valencia, Spain. Retrieved from http://ceur-ws.org/Vol-998/Paper13.pdf

Frederiks, P. J., \& Van der Weide, T. P. (2006). Information modeling: The process and the required competencies of its participants. Data \& Knowledge Engineering, 58(1), 4-20. doi: 10.1007/9783-540-27779-8_11

Garcia, A. C., \& Baker Jacobs, J. (1999). The eyes of the beholder: Understanding the turn-taking system in quasi-synchronous computer-mediated communication. Research on language and social interaction, 32(4), 337-367. doi: 10.1207/S15327973rls3204_2

Hogrebe, F., Gehrke, N., \& Nüttgens, M. (2011). Eye Tracking Experiments in Business Process Modeling: Agenda Setting and Proof of Concept. In Proceedings of EMISA (pp.183-188). Hamburg, Germany. Retrieved from http://dblp2.uni-trier.de/db/conf/emisa/emisa2011.html

Hoppenbrouwers, S., Proper, H. E., \& van der Weide, T. P. (2005). A fundamental view on the process of conceptual modeling. In Proceedings of Conceptual Modeling-ER 2005 (pp. 128-143). Austria: Springer-Verlag. Retrieved from http://link.springer.com/chapter/10.1007/11568322_9

Malone, T. W., \& Crowston, K. (1994). The interdisciplinary study of coordination. ACM Computing Surveys (CSUR), 26(1), 87-119. Retrieved from http://dl.acm.org/citation.cfm?id=174668

Mauser, S., Bergenthum, R., Desel, J., \& Klett, A. (2009). An Approach to Business Process Modeling Emphasizing the Early Design Phases. In Proceedings of the 16th German Workshop on Algorithms and Tools for Petri Nets (AWPN2009) (pp. 41-56). Karlsruhe, Germany. Retireved from http://ceur-ws.org/Vol-501/Paper6.pdf

Mendling, J., Recker, J. C., \& Wolf, J. (2012). Collaboration features in current BPM tools. EMISA Forum, 32(1), 48-65. Retrieved from http://bpm.q-e.at/wpcontent/uploads/2012/08/CollaborativeBusinessProcessModeling.pdf

Petrusel, R., \& Mendling, J. (2013). Eye-tracking the factors of process model comprehension tasks. In Proocedings of International Conference on Advanced Information Systems Engineering CAiSE'13 (pp. 224-239). Valencia, Spain: Springer. Retrieved from http://link.springer.com/chapter/10.1007/978-3-642-38709-8_15

Pinggera, J., Furtner, M., Martini, M., Sachse, P., Reiter, K., Zugal, S., \& Weber, B. (2013). Investigating the process of process modeling with eye movement analysis. In Proocedings of Business Process Management Workshops (pp.438-450). Tallinn, Estonia, Springer-Verlag Berlin Heidelberg. Retrieved from http://link.springer.com/chapter/10.1007\%2F978-3-642-36285-9_46

Riemer, K., Holler, J., \& Indulska, M. (2011). Collaborative process modelling-tool analysis and design implications. In Proceedings of ECIS (pp. 39-45). Helsinki, Finland. Retrieved from http://aisel.aisnet.org/cgi/viewcontent.cgi?article=1038\&context=ecis2011

Rittgen, P. (2010). Success factors of e-collaboration in business process modeling. In Proceedings of Advanced Information Systems Engineering (CAiSE2010) (pp. 24-37). Hammamet, Tunisia, 
Springer Berlin Heidelberg. Retrieved from http://link.springer.com/chapter/10.1007/978-3-64213094-6_4

Roser, S., \& Bauer, B. (2005). A categorization of collaborative business process modeling techniques. In Proceedings of Seventh IEEE International Conference on E-Commerce Technology Workshops (pp. 43-51). Munich, Germany. Retrieved from http://ieeexplore.ieee.org/document/1521009/

Salas, E., Cooke, N. J., \& Rosen, M. A. (2008). On teams, teamwork, and team performance: Discoveries and developments. Human Factors: The Journal of the Human Factors and Ergonomics Society, 50(3), 540-547. doi: 10.1518/001872008X288457

Software AG. (2012). ARISalign space. Retrieved August 2012, from http://www.arisalign.com/.

Stahl, G. (2009). Studying virtual math teams. New York: Springer.

Stahl, G., Zemel, A., Sarmiento, J., Cakir, M., Weimar, S., Wessner, M., \& Mühlpfordt, M. (2006). Shared referencing of mathematical objects in online chat. In Proceedings of the 7 th International Conference on Learning Sciences (pp. 716-722). Bloomington. Retrieved from http://dl.acm.org/citation.cfm?id=1150138\&CFID=693512810\&CFTOKEN=28650001

Strijbos, J.-W. (2009). A multidimensional coding scheme for VMT Studying virtual math teams. In G. Stahl (Ed.), Studying virtual math teams (pp. 399-419). Boston: Springer.

Teddlie, C., \& Yu, F. (2007). Mixed methods sampling a typology with examples. Journal of mixed methods research, 1(1), 77-100. doi: 10.1177/2345678906292430

Weske, M. (2007). Business process management: concepts, languages, architectures. Springer, Heidelberg.

Woods, D, and Fassnacht, C. (2007). Transana v2.20. In Madison, WI: The Board of Regents of the University of Wisconsin System. Retrieved from http://www.transana.org.

Zemel, A. (2005). Texts-in-interaction: Collaborative problem-solving in quasi-synchronous computermediated communication. In Proceedings of the 2005 conference on Computer support for collaborative learning: learning 2005: the next 10 years! (pp. 753-757). Taipei, Taiwan. Retrieved from http://dl.acm.org/citation.cfm?id=1149392\&CFID=693512810\&CFTOKEN=28650001

Zemel, A., Xhafa, F., \& Cakir, M. (2007). What's in the mix? Combining coding and conversation analysis to investigate chat-based problem solving. Learning and Instruction, 17(4), 405-415. doi: 10.1016/j.learninstruc.2007.03.006 
AJIT-e: Online Academic Journal of Information Technology

2018 Yaz/Summer - Cilt/Vol: 9 - Sayı/Num: 33

DOI: 10.5824/1309-1581.2018.3.001.x

http://www.ajit-e.org/?menu=pages\&p=details_of_article\&id=349 